\title{
0 Federalismo como Experiência: Campos Sales e as Tentativas de Estabilização da República*
}

\author{
Cláudia Maria R. Viscardi \\ Universidade Federal de Juiz de Fora (UFJF), Juiz de Fora, MG, Brasil. E-mail: \\ claudiaviscardi.ufff@gmail.com
}

W este artigo procuraremos fazer uma análise específica sobre a teve à frente da Presidência do país, com o objetivo de avaliar o impacto da mesma sobre a estabilização dos conflitos políticos da nascente República. A partir da investigação feita sobre novas fontes, acreditamos poder contribuir um pouco mais para o debate sobre o tema.

O governo Campos Sales foi objeto de inúmeros estudos, desde os que lhe foram contemporâneos até trabalhos mais recentes. Para além das biografias produzidas por familiares, amigos ou ex-colaboradores, todas elas de caráter bastante elogioso e enaltecedor de seus feitos ${ }^{1}$, a literatura propriamente acadêmica acabou, em nosso entendimento, por repercutir o esforço desses trabalhos em conferir à reforma dos estados um poder maior do que ela efetivamente teve.

A década de 1970 testemunhou uma série de referências deste tipo, a exemplo dos trabalhos de Edgar Carone, que responsabilizam Sales por ter consolidado a permanência dos mesmos grupos no poder, ao congelar a disputa política nacional, como se vê abaixo, em duas de suas obras:

\footnotetext{
* Este artigo é resultante de pesquisas desenvolvidas com apoio da Fundação Casa de Rui Barbosa, do Conselho Nacional de Desenvolvimento Científico e Tecnológico (CNPq) e da Fundação de Amparo à Pesquisa do Estado de Minas Gerais (Fapemig).

DADOS - Revista de Ciências Sociais, Rio de Janeiro, vol. 59, no-4, 2016, pp. 1169 a 1206.
} 
A política dos governadores restringe todas as possibilidades do jogo eleitoral e dos métodos de luta pelo poder (Carone, 1983:194).

Dentro desta estrutura jurídico-pragmática é que Campos Sales consolida um sistema pragmático-jurídico: tendo assistido às contínuas lutas oligárquicas no plano estadual e às revoluções delas resultantes, ele concebe uma fórmula de consolidação e permanência dos grupos que estivessem no poder, sem permitir qualquer abertura às oposições (Carone, 1988:299, ênfases minhas).

Assim completa-se o mecanismo de pressão dos grupos dominantes, cuja permanência se torna inexorável (ibidem:309, ênfases minhas). Para Carone, o maior feito da política dos estados foi a estagnação da vida representativa do país. Voltada especialmente para impedir a ascensão de grupos oposicionistas, ela teria engendrado a participação contínua de uma maioria a controlar de forma permanente o regime.

A mesma concepção se percebe, ainda na década de 1970, na abordagem de Fernando Henrique Cardoso (1975:47-48). Para ele, a monarquia conseguia manter boas relações entre o Executivo e o Parlamento em razão do papel do Poder Moderador, a controlar a formação dos gabinetes segundo o arbítrio do Imperador. Extinto o quarto poder com a República, não havia nenhum mecanismo de controle das dissidências entre os dois poderes, o que foi obtido após a reforma Campos Sales. A política dos estados teria um papel substitutivo ao do Poder Moderador.

A tão pobre esqueleto real [o Poder Moderador] reduzia-se, na verdade, a ossatura da doutrina Campos Sales. Com ela, entretanto, complementara-se a institucionalização do sistema oligárquico. Se este vinha do passado como uma característica local, ganhou foros de sistema nacional de dominação (...) (Cardoso, 1975:49).

Para Cardoso, a política dos estados, além de ter resolvido o problema advindo da falta do Poder Moderador, contribuiu para a institucionalização do regime, ao torná-lo menos personalizado.

Souza também reconheceria na reforma de Sales o papel estabilizador dos conflitos políticos da Primeira República, conferindo-lhe uma longevidade só interrompida após a Revolução de 1930, como vemos a seguir:

Com o apoio de três bancadas numerosas, Campos Sales conseguiu que suas diretrizes fossem cumpridas. Resolveu assim os problemas partidários mais importantes da atividade política, aqueles relacionados à 
formação das estruturas de dominação nos Estados. (...) Instituíra-se a norma básica da "política dos governadores" que deveria propiciar ao regime federativo o equilíbrio procurado nos anos anteriores. Sob sua égide fluiria a República até 1930 (Souza, 1985;184-185, ênfases minhas).

Na mesma linha, Hélio Silva atribuiu a Campos Sales a responsabilidade por ter iniciado com suas reformas a institucionalização da farsa eleitoral. Sua abordagem nos leva a entender que a Revolução teria ancorado sua justificativa no combate às fraudes eleitorais, consolidadas pela política dos estados.

O exame das atas revelava que as eleições oficiais eram uma farsa. (...) $\mathrm{O}$ Congresso, instalado em 1900 iria iniciar uma era de mentira eleitoral, de inautenticidade da representação que viria a ser o cancro que correria as instituições e constituindo a mais séria justificativa da Revolução de 30, que destruiu a República Velha (Silva, 1975:101-102).

Os vínculos entre a reforma e a revolução de 1930 acima observados já haviam sido feitos previamente por Melo Franco em obra publicada em 1955: "Na verdade foi a política dos estados, sem partidos nacionais, que conduziu o Brasil à Revolução de 30, crise de exacerbação máxima da política estadual..." (Franco, 1955:479).

Alguns anos depois, já na década de 1980, o brasilianista J. Wirth, que estudara Minas Gerais entre 1889 e 1937, reforçaria a tese do papel estabilizador das medidas de Sales ao afirmar que:

O sistema presidencial tornou-se estável em 1900 com a famosa política dos governadores. Este pacto entre Campos Sales e os principais estados permitia-lhes expurgar os dissidentes no Congresso, garantindo ao mesmo tempo apoio para seu programa de austeridade (Wirth,1982:232, ênfases minhas).

Próximo ao final da década, Renato Lessa publicaria a Invenção Republicana, livro dedicado à análise do impacto da política dos estados sobre o ordenamento e estabilização da República. Lessa se valeu da autobiografia de Sales para fundamentar a criação de modelos analíticos que apontaram para a "rotinização" de procedimentos ao longo da República. Para o autor, tais procedimentos resolveram as instabilidades geradas pelo fim do Poder Moderador, constituindo-se a política dos estados em seu equivalente funcional, o que marca uma retomada da tese de Cardoso citada anteriormente (Lessa, 1988:111). Em razão do caráter inovador de suas abordagens e da inexistência de estudos mais 
analíticos e menos retóricos acerca de Campos Sales, o livro tornou-se importante referência para os estudos do tema no Brasil.

Para o autor, o modelo de Campos Sales tinha duas facetas: a procedural e a substantiva. A primeira se constitui nas reformas regimentais, e a segunda diz respeito aos valores que Campos Sales atribuía ao próprio modelo, sobretudo a concernente à despolitização de seu governo (ibidem:15). Tal como os autores anteriores, para Lessa o governo de Campos Sales representaria o início da rotinização do regime republicano (ibidem:99) e sua política dos estados promoveria a desnacionalização da competição política (ibidem:157).

A década de 1990 manteria a perspectiva dominante, a exemplo dos trabalhos de Penna (1989:96-97), Mendonça (1990:230) e Francisco Iglésias (1993), que afirma que através da política dos estados

Chega-se assim à forma ideal de conciliação, que é, na verdade, a conciliação dos estabelecidos no poder, um acordo baseado não em programas ou ideias, mas em continuísmo: uma transação, um negócio. (...) A política dos governadores representa uma distorção do federalismo, denuncia o vício essencial da república velha. (...) Como a política de Campos Sales representa o máximo de composição com os estados, tem-se então a plenitude do coronelismo (1993:208-209, ênfases minhas).

Como podemos ver, Iglésias associa as reformas de Sales à ausência de renovação política, às distorções do federalismo e à garantia do coronelismo. Teria garantido ao novo regime a conciliação entre os diferentes interesses em luta, o que propiciaria a continuidade do regime.

Em trabalho mais recente, percebe-se a prevalência da mesma abordagem que confere preponderância ao caráter estabilizador das reformas de Campos Sales. Trata-se de uma tese de doutorado, defendida em 2004 e publicada dois anos depois, que se dedicou ao estudo do pacto de Campos Sales. Ana Luiza Backes afirma que na primeira década republicana predominaram cisões políticas que se explicavam pelas divergências de fundo ideológico, e não regionais ou classistas, como apontavam outros autores. Para a autora, tal quadro seria alterado após a política dos estados, responsável pela estadualização da representação política, tornando as divergências regionais. Para ela, antes da política dos estados os governadores não controlavam suas bancadas (2006:171), o que leva a crer que, após essa medida, passaram a controlar. A autora não escapa da tese predominante que delega a Sales 
e sua reforma o poder de ter tornado rotineiras as práticas ao mesmo tempo regionalistas e coronelistas da Primeira República:

O padrão de representantes totalmente fiéis aos governadores apenas se consolida depois da reforma do Regimento, que estabiliza a representação política (...). A partir da reforma, o acordo é que o Congresso reconhecerá quem vier referendado pela oligarquia dominante no estado, acabando com as chances das minorias estaduais (ibidem:172-178).

No entanto, a autora preserva o papel do presidencialismo, na medida em que a conservação de determinados grupos no poder nos estados dependia em última instância do aval do presidente. Esta conclusão se contrapõe ao processo de regionalização ocorrido e a autora não esclarece de que forma o presidente poderia interferir, uma vez que acatava as decisões dos governadores na composição de suas respectivas bancadas.

Como se vê, após o interregno "entrópico" - tomando por empréstimo a expressão de Lessa (1988) -, caracterizado por árduas divergências políticas que dividiam o Parlamento e a sociedade civil brasileira como um todo, a Campos Sales é atribuído o êxito em aquietar os ânimos e criar novas regras de convivência. Ao mesmo tempo, teria conseguido reverter os principais problemas decorrentes da crise do Encilhamento, impondo dura derrota aos papelistas ${ }^{2}$, organizar melhor o Poder Judiciário e, a despeito de sua imensa impopularidade, fazer o seu sucessor. Campos Sales foi exitoso em seu projeto de governo e de Estado, ao ser visto até os dias de hoje como o grande consolidador do regime republicano brasileiro.

Boa parte de seu êxito é explicada pela implantação da política dos estados, que se deu a partir de uma reforma no Regimento Interno da Câmara de Deputados, no ano de 1899. Seu objetivo com a reforma era o de tornar o Congresso estável, livre das divergências que o dividiam nos períodos anteriores.

Em trabalho anterior (Viscardi, 2012:37), sugerimos que o papel estabilizador da política dos estados merecia ser relativizado. Tomando como premissa este desafio autoimposto, pretendemos investigar como a política dos estados foi operacionalizada e quais os impactos dela advindos no curto e médio prazos. Para este fim, será necessário analisar as reformas anteriores e posteriores ao Regimento da Câmara para avaliar a originalidade e a longevidade das medidas estabilizado- 
ras propostas e, por conseguinte, avaliar a sua eficácia ${ }^{3}$. Por esta razão, estenderemos nossa análise para além de seu governo.

Como os Regimentos Internos aludem às leis eleitorais em vigor na época, iremos analisá-las, quando necessário. A partir de uma relação entre leis eleitorais e regimentos parlamentares, buscaremos contribuir para uma melhor compreensão do processo eleitoral republicano.

Não obstante tangenciarmos discussões acerca do processo eleitoral da Primeira República, nosso fim primeiro é o de analisar o real impacto da política dos estados sobre os processos macropolíticos, defendendo o argumento de que o papel atribuído à reforma como estabilizadora dos conflitos políticos foi uma construção de seu próprio autor, referendada em boa parte por estudiosos que lhes foram posteriores.

\section{TENTANDO ESTABILIZAR O AVIÃO EM PLENO VOO: MECANISMOS ANTERIORES À "POLÍTICA DOS ESTADOS"}

Os conflitos políticos da primeira década republicana desmentiriam os contemporâneos que pensavam ter encontrado a fórmula mágica da estabilidade: o veto ao acesso ao poder pela maioria da população. Libertos, imigrantes empobrecidos, vadios e subempregados, todos eles apartados da política, não seriam os responsáveis por colocar o novo regime em risco. Excluídos da participação política formal, aceitavam mais ou menos passivamente o papel de figurantes de um espetáculo que pouca importância tinha diante de outros atrativos à sua disposição. A República estava ameaçada por dentro, pelos conflitos intraelitistas que ela mesma havia engendrado e que sérias repercussões causariam a sua manutenção. A guerra civil no Rio Grande, a Revolta da Armada, os motins restauradores, o jacobinismo radical, entre outros movimentos, fortaleciam as prerrogativas daqueles que ansiavam pelo estabelecimento de uma ditadura militar republicana ou dos que, ao contrário, atribuíam ao controle militar do regime as mesmas instabilidades, apostando no afastamento definitivo das forças do Exército da política, ou mesmo no fim do próprio regime republicano ${ }^{4}$.

Os esforços pacificadores de Floriano e Prudente foram capazes de colocar ordem na casa, mas insuficientes para garantir a governabilidade. As árduas disputas travadas no Parlamento pelo controle das ações por parte das facções em luta ameaçavam a estabilidade constitucional, cuja expressão máxima foi a tentativa de assassinato do chefe do 
Executivo. Mesmo frustrada, revelou o alto grau da crise política instaurada e trouxe à baila o fantasma da restauração.

A incompletude do projeto republicano, construído frouxamente ao longo da propaganda de quase 20 anos, foi uma das razões que conduziram às instabilidades observadas nos primeiros anos do novo regime. Para além da fragilidade dos compromissos previamente assumidos e que orientariam a construção da República, pesavam os anseios de incorporação à esfera do poder de novos agentes, que não lograram o êxito desejado, uma vez que o cobertor era curto para tantos desabrigados. A estratégia de se construir o projeto republicano pela via do reformismo, com base no convencimento engendrado por massiva propaganda em comícios e conferências, havia levado o projeto para as ruas, envolvendo vários setores que se tornariam sequiosos por participar da nova construção que se esboçava. O resultado não fora o desejado. Ao contrário: conhecidas foram as exclusões dos radicais republicanos, dos militares jacobinos, dos positivistas, de funcionários públicos e de outros setores, o que provocou uma insatisfação generalizada em relação ao novo regime. As promessas de cunho salvacionista expressas pelo projeto mudancista - anunciado como uma panaceia capaz de resolver as mais profundas crises do velho regime-enchiam de expectativa os novos adeptos, que tão logo decepcionados, revoltaram-se nas mais variadas frentes, com os recursos que dispunham. Em síntese, como o projeto republicano era aberto e inconsistente, a disputa pelo que seria o novo regime seria travada arduamente em seus primeiros anos.

Talvez por esta razão se atribua tanta importância ao governo Campos Sales. Como visto, Sales teria sido o arquiteto final do projeto republicano, uma vez que a partir de seu mandato as instabilidades que tanto ameaçavam a República foram arrefecidas ou confinadas ao interior das próprias oligarquias estaduais.

\section{O PROCESSO ELEITORAL E A VERIFICAÇÃO DE PODERES}

O complexo processo eleitoral para o Parlamento federal republicano envolvia uma série de etapas. A primeira consistia no alistamento, ou qualificação dos eleitores, a qual era cumprida após a emissão de títulos eleitorais e a disponibilização pública de uma relação de eleitores qualificados para o voto. A segunda etapa consistia na realização das eleições em si, em dias previamente determinados, quando algumas 
regras deveriam ser obedecidas para que o eleitor pudesse livremente exercer seu direito de escolha. O voto era facultativo. A terceira era a da apuração, quando as urnas eram abertas, as atas eram redigidas e, depois, remetidas a setores responsáveis pela contagem final dos votos, validação de processos e divulgação de resultados. Por fim ocorria a verificação de poderes, ocasião em que o processo era revisto em seu todo e os candidatos eleitos eram finalmente empossados, estando aptos a exercer suas funções públicas.

As três primeiras fases deste longo processo eram regulamentadas pelas constituições (da Federação e dos estados) e pelas leis eleitorais, continuamente alteradas ao longo dos anos. Tais alterações revelavam ajustes de rota, a partir de experiências acumuladas por várias eleições. Já a quarta e última fase (a de verificação de poderes), envolvia ações exclusivas do Parlamento e eram reguladas pelos seus Regimentos Internos, os quais previam a dinâmica de funcionamento das comissões verificadoras.

Segundo Magalhães (1986:28-30), as origens das comissões de verificação de poderes no Brasil remontam ao ano de 1823, quando fora instalada a primeira assembleia constituinte. Para a sua composição foram designadas duas comissões, de cinco e três membros, respectivamente: a primeira com o fim de verificar a legalidade dos diplomas emitidos e a segunda, encarregada de verificar exclusivamente os diplomas dos membros da primeira comissão. Tal conformação permaneceu até 1857, quando as duas comissões tornaram-se uma só, de 21 membros.

O primeiro Regimento Interno da Câmara republicana é o de 1891. Iremos nos deter aqui na análise de cinco regimentos, entre eles o que resultou da reforma Campos Sales 5 . Acreditamos que através desta pesquisa seja possível mensurar as mudanças ocorridas no processo de verificação de poderes, desde que relacionados às leis eleitorais do período.

O início efetivo das atividades parlamentares era precedido de sessões preparatórias, cuja finalidade era a de definir a própria composição dos membros do Parlamento. De nada bastariam os esforços empreendidos pelos candidatos em prol de sua eleição caso fosse ela contestada por algum concorrente. De 15 a 30 dias antes da abertura oficial dos trabalhos legislativos, dependendo do regimento em vigor, reunir-se-iam os deputados pretensamente eleitos, os quais apresentariam ao presidente e aos seus quatro secretários auxiliares os seus respectivos diplo- 
mais eleitorais. Mantendo-se a forma como se procedia no período imperial, o presidente seria o membro diplomado de maior idade e seus auxiliares seriam por ele indicados entre os que aparentassem ser os mais novos ${ }^{6}$. Os diplomas seriam separados em duas listas: uma sem contestações e outra em que estas se faziam presentes. Da primeira lista seriam sorteados 25 nomes divididos em cinco comissões ${ }^{7}$ para análise e emissão de pareceres referentes às contestações apresentadas. Iniciava-se assim o quarto e último ato do teatro eleitoral, definitivo em relação aos destinos dos pleiteantes, a verificação de poderes.

A cada uma das cinco comissões, chamadas de comissões de inquérito, era atribuída a análise de processos eleitorais de estados diferentes, sendo que não era permitido aos deputados verificar as contestações de seus próprios estados de origem. Todo este processo era público, e suas conclusões eram divulgadas pela imprensa. Os contestantes poderiam ser representados por advogados ou por outros deputados. Travava-se um debate em torno da veracidade ou não das atas eleitorais apresentadas e, ao final, cabia às comissões emitirem um parecer, que deveria incluir os votos em separado de seus membros ou emendas às deliberações, caso surgissem. Quando as decisões da comissão não alcançassem maioria, além de seu relatório, seriam apreciados os votos em separado em plenário, exigindo-se para deliberação o quórum mínimo de metade mais um dos eleitos. Definidos os membros da Câmara, eram eleitos seus gestores (presidente, vice e secretários) e os membros das demais comissões. Somente depois de cumpridas estas sucessivas etapas o Parlamento estaria habilitado a iniciar a sua rotina.

Tendo em vista as similaridades entre o novo regimento republicano e o que lhe antecedia no período imperial, como explicar o efeito desagregador provocado pelo processo de verificação de poderes sobre a Câmara? Após a extinção do Poder Moderador e a introdução do federalismo, que se baseava em unidades autônomas, descentralizadas e desiguais entre si, as disputas entre os estados-atores encontraram campo aberto para livre manifestação. O fato de o responsável pela condução do processo ser o membro mais velho e ter livre direito de escolha dos membros da comissão dos cinco tornou o Parlamento um campo de disputa pelo controle de sua própria renovação. Parte da crise política que assolou os governos de Floriano e Prudente resultou da ausência de mecanismos de controle que não existiam mais. Foi por esta razão que Renato Lessa (1988:111) associou a política dos estados de Sales a um equivalente funcional ao Poder Moderador. 


\section{Leis Eleitorais}

No que diz respeito às leis eleitorais, interessa-nos tão somente ressaltar referências aos processos de apuração e verificação de poderes, no período anterior à reforma de Sales.

O Decreto 511, de 23 de junho de 1890, que regulou as eleições para o primeiro Congresso pós-constituinte, estabelecia que as apurações parciais dos resultados eleitorais fossem feitas imediatamente após o encerramento da votação pelas próprias mesas encarregadas do processo, no âmbito dos municípios. À exceção das cédulas invalidadas que seriam remetidas a um segundo escrutínio posterior - as demais deveriam ser queimadas. Apenas os resultados expressos nas atas (chamadas "autênticas"), acrescidos dos protestos e contestações, seriam remetidos às juntas apuradoras dos estados e ao Ministério do Interior e Justiça. Desta forma, um segundo escrutínio, de caráter geral, seria feito nas capitais dos estados, a partir da soma dos resultados das autênticas enviadas pelas circunscrições eleitorais municipais. Percebe-se que, no início da República, o controle de todo o processo eleitoral passava pelos municípios.

A Lei Eleitoral no 35 de 26 de janeiro de 1892, que tratava das eleições federais, retirou a referência à queima de cédulas e passou a prever que toda a documentação relativa aos processos eleitorais fosse arquivada. Ainda no que tange à apuração, sua ata passaria a ser registrada junto ao tabelião local e depois remetida à junta apuradora para apuração geral. O parágrafo 60 do artigo 44 da referida lei previa que à junta apuradora caberia tão somente somar os votos das autênticas, tendo, todavia, o direito de mencionar em sua ata quaisquer dúvidas em relação ao processo. Previa também a lei que, em caso da existência de duplicatas, caberia à junta apuradora levar em conta apenas a eleição ocorrida no local previamente designado (§ 7, art. 44). Um ano depois, conferiu-se maior poder às juntas apuradoras dos estados, e houve uma maior preocupação com a manutenção das cédulas, propiciando eventuais recontagens.

Pela primeira vez na República uma lei eleitoral fazia alusão ao processo de verificação de poderes, embora ela já estivesse prevista pela Constituição Federal, em seu art. 18:

A Câmara ou Senado, sempre que no exercício do direito de reconhecimento dos poderes dos seus membros, anular uma eleição sob qualquer 
fundamento, resultando desse ato ficar o candidato diplomado inferior em número de votos ao imediato, deverá determinar que realize nova eleição ${ }^{8}$ (ênfases minhas).

Percebe-se a partir da citação que o poder da comissão de verificação fora ampliado, conferindo-lhe poderes de anular todo um processo eleitoral e de recomendar a realização de outro. Em seu conjunto, entende-se que o processo de apuração era complexo e extrapolava os limites de atuação das câmaras de verificação de poderes do Parlamento. O controle dos resultados pertencia inicialmente aos municípios, responsáveis pelos processos de alistamento, eleição e apuração dos votos. Os conflitos que não conseguiam se resolver - relativos a contestações e duplicações de resultados, provavelmente relacionadas às disputas intraoligárquicas - eram repassados à outra esfera - a das juntas apuradoras - que sob o controle de lideranças estaduais, tomavam decisões e, após esta etapa, cabia à comissão de verificação de poderes a decisão final. Esta relação é que fundamentava todo o compromisso coronelista, entre o chefe municipal e a liderança estadual e federal, como nos revelou Leal (1993).

O que se destaca é que durante o período em que prevaleceu a possibilidade de queima de cédulas, restavam às juntas apuradoras poucos instrumentos de controle, caso necessitassem. Quando introduzido o posterior arquivamento do material eleitoral, ampliou-se a margem de controle das juntas e das comissões de inquérito, caso desejassem recontar os votos. Mesmo assim, em obediência ao já conhecido compromisso coronelista, este controle de resultados era tarefa das lideranças municipais, preservando na instância estadual e federal certa margem de manobra apenas no caso de duplicatas e de contestações. O termo "depuração", usado pelos próprios contemporâneos em alusão ao processo em seu conjunto, funcionava como excelente metáfora ilustrativa de suas diversas fases. Os mecanismos de apuração agiam como sucessivos filtros para que os escolhidos pudessem atuar sob o rígido controle de chefias locais, estaduais e federais. Este modelo de federalismo que se esboçava era a garantia de que as oposições permanecessem à margem do processo de decisão, garantindo-se a continuidade e preservação dos mesmos grupos no poder.

O Decreto nํㅜ 1.542 de 1ํ de setembro de 1893 inovava por ampliar o direito ao protesto dos vencidos. Poderiam os mesmos pedir que os resultados fossem novamente verificados pela mesa e poderiam inserir 
nas autênticas seus protestos em relação aos resultados certificados pelas maiorias consolidadas nos municípios (art. 17, §§ 15 e 19). Nota-se através desta mudança que cada vez mais os municípios repassavam seus conflitos para as juntas apuradoras com sede nos estados. Ao fazerem isto, perdiam autonomia, mas talvez esta fosse a única forma de obterem consensos possíveis no âmbito de suas sedes. Permitia este regulamento que as atas de apuração assinadas por minorias fossem também enviadas às juntas apuradoras para serem analisadas. Com o tempo, concentrava-se nas juntas, com sedes nas capitais dos estados, a maior parcela de controle sobre a renovação do Parlamento.

Em pesquisa nas leis eleitorais do período só encontramos referência à composição das Juntas nos estados a partir de 1893. Elas seriam compostas pelo governador do Estado, os cinco membros mais votados e os cinco imediatos aos menos votados ${ }^{9}$. Três anos mais tarde, ressaltava-se a possibilidade de haver coincidência entre os membros das mesas eleitorais e os das juntas apuradoras. Tal composição só mudaria em 1904, com a Lei Rosa e Silva.

As leis subsequentes até 1899 pouco alteraram o processo de apuração. Destaca-se um forte papel exercido pelo Executivo sobre todo o processo, tanto em âmbito municipal como estadual. Na ausência de um judiciário estruturado, cabia ao Executivo controlar todo o processo de recrutamento político.

Pelo que pôde ser visto até agora, os primeiros anos do novo regime foram marcados por sucessivas tentativas de regulamentar a participação popular na política e limitar o acesso das minorias. Ao mesmo tempo, criavam-se canais de manifestação de descontentamentos, provavelmente por não apostarem muito na confiabilidade do sistema e também por desejarem manter parte dos princípios da democracia formal. Tais perspectivas ilustram bem os limites da soberania popular anunciada desde a propaganda republicana, os quais expressavam a um só tempo a crença nos valores liberais e republicanos e os temores em relação à participação do povo na política.

Vimos também que o processo era complexo e envolvia fases cumulativas distintas, num processo de depuração de nomes que, embora apontassem para a manifestação da vontade do eleitor expressa nas urnas, abria inúmeras janelas de oportunidades para que a intervenção sobre os resultados ocorresse, colocando todo o processo em risco. 
Não obstante o fato de as eleições se darem sob o controle dos municípios, a apuração desenvolvia-se sob a guarda dos estados e o reconhecimento, sob a égide do Parlamento. É difícil aferir qual das instâncias - municipal, estadual ou federal - tinha mais controle sobre o processo, pois todas tinham poder de interferência sobre o mesmo. O segredo de seu sucesso seria a perfeita articulação entre elas, o que nem sempre ocorreu. O arbítrio final se dava, no entanto, no Parlamento, mas como veremos, a inclusão ou exclusão dos candidatos dependia do voto nos municípios e da apuração final nos estados, fases sem as quais dificilmente um nome chegava ao reconhecimento. E mesmo ao chegar, poderia vir frágil, ou seja, acompanhado de contestações. Um processo com este grau de complexidade desautoriza avaliações simplistas ou esquemáticas sobre sua dinâmica.

\section{A REFORMA DE 1899 E OS NOVOS RUMOS DO FEDERALISMO BRASILEIRO}

A política dos estados de Campos Sales era a manifestação clara de um modelo específico de federalismo que ele projetava para o país. Naquele contexto, sua avaliação era de que a República encontrava-se ameaçada em razão das dissidências internas que ocorriam no âmbito do Parlamento. Para resolvê-las, sua opção foi por atuar no próprio órgão, intervindo exclusivamente sobre a quarta e última fase do processo eleitoral: a da verificação de poderes.

Quando Sales assumiu, em 1898, os principais conflitos de rua haviam arrefecido. O movimento de Canudos, que tantos problemas trouxera para a gestão de Prudente, havia sido derrotado. Os jacobinos ${ }^{10}$ encontravam-se fragilizados após a malsucedida tentativa de homicídio contra o chefe da nação, e essa conjuntura possibilitou a realização de uma eleição pacífica. O Congresso, composto ainda pelos mesmos deputados que se dividiram no governo Prudente, uniu-se em torno do novo líder (Sales, 1983:107). Tudo parecia entrar em ordem, e ao longo do primeiro ano de seu mandato Sales conseguiu governar com relativa tranquilidade.

No entanto, conhecedor que era da conjuntura política de seu tempo, sabia que a anunciada renovação da Câmara, que se daria durante seu governo - fato que ocorreu em algumas presidências, visto que o mandato presidencial era de quatro anos e o de deputados de três - se constituiria em ameaça à estabilidade, uma vez que a trégua na disputa entre republicanos e concentrados, estabelecida após sua posse, poderia 
ter fim. A experiência pretérita havia ensinado aos antigos mandatários da nação que a renovação do Parlamento era um ponto de estrangulamento do sistema, dado o recrudescimento de divergências.

Antecipando-se à ameaça anunciada, empreendeu esforços no sentido de conter uma das inúmeras válvulas de escape do novo regime: as disputas no interior do Parlamento em torno de sua própria renovação. Foi de iniciativa de Campos Sales a proposta apresentada pelo deputado Augusto Montenegro, ao final do ano de 1899 de reforma do Regimento Interno da Câmara.

\section{A Reforma no Parlamento}

Com poucas oposições, a reforma foi aprovada, em 30 de outubro daquele ano ${ }^{11}$. Para Alcindo Guanabara, a aprovação das medidas foi garantida por uma negociação política encetada diretamente por Campos Sales com os governadores de alguns estados. Silviano Brandão, de Minas Gerais, foi consultado e pôde garantir o apoio da numerosa bancada mineira ao projeto. Sem o apoio dos governadores dificilmente o modelo teria sido aprovado e, ao fim e ao cabo, exitoso. Na interpretação de Guanabara, "Foram os representantes dessas organizações estaduais que acudiram ao chamamento patriótico do Presidente e contribuíram para constituir no Congresso a firme maioria em que ele se apoiou" (1983:90).

Para Campos Sales, a reforma de 1899, chamada pelos contemporâneos de "política dos governadores", era na prática uma "política dos estados". Em seu modelo de federalismo, a soberania estaria sediada nos estados e não no Parlamento ou nos indivíduos privados. De certa forma esta premissa deveria ser garantida no âmbito do Congresso, composto em essência pelas bancadas dos estados. Mas parece-nos que na avaliação de Sales o problema do federalismo brasileiro estava na má relação entre a União e os estados-membros da Federação, o que ele planejava resolver. Percebia que nem sempre as bancadas obedeciam ao controle dos governadores, o que prejudicava o acordo entre o Executivo e o Legislativo.

Nessa, como em todas as lutas, procurei fortalecer-me com o apoio dos estados, porque - não cessarei de repeti-lo - é lá que reside a verdadeira força política. Na monarquia inglesa, como na república americana, é das unidades do poder local que converge a ação para o centro. (...) O meu pensamento era proporcionar a todos os grupos garantias iguais, 
com absoluta imparcialidade, de modo a evitar a vitória ilegítima e absorvente de um deles. (...) Em nada me preocupava o resultado do pleito, na medida em que teria ele de representar a vitória da opinião predominante em cada estado. A política dos estados, isto é, a política que fortifica os vínculos de harmonia entre os estados e a União é, pois, na sua essência, a política nacional. É lá, na soma dessas unidades autônomas, que se encontra a verdadeira soberania da opinião. O que pensam os estados pensa a União (Sales, 1983:127, ênfases minhas).

Em seu modelo de federalismo, o Congresso deveria espelhar a vontade dos estados, e não a dos eleitores privados ou dos grupos corporativos. Este modelo não era novo e nem o estadunidense, que Sales tanto admirava, mas sim o francês, no qual o Parlamento se constituía enquanto expressão da vontade geral. Para Sales, no entanto, a vontade geral não seria necessariamente expressa pela vontade das urnas, e sim pelas opiniões dominantes em cada estado, o que de certa forma conferia ao modelo francês uma certa especificidade.

Segundo o novo Regimento, proposto por Sales e aprovado pelo Parlamento, as sessões preparatórias, encarregadas de realizar a verificação de poderes, seriam presididas pelo último presidente da legislatura anterior, desde que este tivesse sido reeleito. Caso contrário, seria mantida a regra antiga, ou seja, a sessão seria presidida pelo deputado mais velho entre os presentes (capítulo 1, artigo 1). Caberia à Presidência, assessorada por quatro secretários por ela escolhidos entre os mais jovens, receber os diplomas dos eleitos que estivessem presentes no recinto.

Tal modificação, aparentemente inofensiva, poderia ter impactado fortemente na administração dos conflitos internos ao Parlamento. Como a escolha do presidente da Câmara ocorria anualmente, era de se supor que seu presidente anterior expressasse o consenso possível entre os pares, o que nem sempre ocorria ao se escolher o mais velho membro para presidir as sessões preparatórias, conforme se dava antes de ser aprovada a reforma de Sales. As sessões preparatórias seriam presididas por alguém que tivesse maior liderança e maior autoridade moral para a condução de um processo em geral muito instável. Ao mesmo tempo, a escolha do presidente da Câmara resultava de inegável influência da Presidência da República sobre o Congresso, o que tornava o presidente da Câmara um aliado do Executivo.

Outra modificação relevante dizia respeito à legitimidade ou não dos diplomas a serem apresentados à mesa então formada. Previa o artigo 
4 do novo regimento que o diploma legítimo seria aquele assinado pela maioria dos membros da junta apuradora nos estados. Como se justificava tal alteração? Era comum a presença de um maior número de deputados que se diziam eleitos do que o número de vagas disponíveis. Isto porque as juntas apuradoras emitiam resultados distintos para um mesmo processo eleitoral, uma vez que as divisões políticas eram muitas e os responsáveis pelo processo eleitoral nos municípios não conseguiam resolvê-las, preferindo exportá-las para uma instância superior. É o que conhecemos por duplicatas eleitorais. Convém destacar que as leis eleitorais tentaram em vão impedir as duplicações de resultados. Recomendavam que, em caso de duplicatas, só fossem apuradas as urnas que tivessem funcionado em local antes previsto. Tal procedimento pode ter inibido a duplicação de resultados, mas não impediu que ocorressem.

Em geral, diante das pressões, as juntas apuradoras enviavam resultados eleitorais contraditórios. A partir da mudança regimental propostas seriam considerados legítimos diplomas assinados pelas maiorias construídas no interior dos estados.

Este procedimento, aparentemente simples, tinha presunção de eficácia garantida, na medida em que pressupunha que os conflitos tivessem que ser previamente resolvidos no âmbito dos executivos municipais e estaduais antes de chegarem ao Parlamento federal. A ideia era que cada estado se responsabilizasse por harmonizar-se internamente, construindo um consenso que se refletiria no Legislativo, permitindo ao Executivo governar em paz com o Congresso. Ao mesmo tempo impedia que o Parlamento alterasse sobremaneira o que havia sido decidido pelas juntas apuradoras nos estados, esvaziando-se seu poder de arbítrio e fortalecendo o situacionismo dos estados, ao esvaziar-se a comissão de verificação de poderes. A importância deste novo procedimento foi ressaltada por Alcindo Guanabara:

Assim, o eixo do pleito eleitoral foi deslocado. Já não se tratava de garantir o presidente provisório a uma das parcialidades, a fim de que dele se obtivesse uma "comissão dos cinco" capaz de eliminar os diplomas líquidos dos adversários. A importância dessa comissão, que seria, no fim de contas, no regime anterior, a grande eleitora da Câmara, estava consideravelmente reduzida. O êxito da eleição dependia agora quase decisivamente de assegurar cada parcialidade a maioria das juntas apuradoras, para obter delas que rejeitassem as contestações ofere- 
cidas e assinassem em maioria, como límpidos e cristalinos, os diplomas de seus correligionários (1983:61).

Na possibilidade de as juntas apuradoras continuarem a remeter atas com resultados diferentes entre si, a resolução previa que os diplomas assinados pela minoria das juntas apuradoras não seriam descartados o que talvez tivesse sido uma decisão mais adequada - mas seriam considerados como contestações. A expectativa de Guanabara é que as juntas evitassem as contestações e enviassem uma só ata ao Parlamento. Como previa o Regimento, cinco comissões formadas por cinco membros cada, escolhidos por sorteio, analisariam os diplomas contestados, com base na documentação eleitoral completa enviada pelas juntas apuradoras à secretaria da Câmara Federal (artigo 5).

Na prática, esta segunda alteração pouco mudava a rotina das comissões de inquérito. Antes as comissões debruçavam-se sobre as contestações enviadas por candidatos. A partir da reforma, as contestações passaram a ser também as atas assinadas pela minoria das juntas apuradoras, agregadas a uma vasta documentação produzida ao longo do processo eleitoral. Considerando-se que os processos de apuração de resultados eram organizados nos municípios e, posteriormente, nas capitais dos estados, e que contavam com a participação de membros mais e menos votados no processo eleitoral (artigo 44 da Lei Eleitoral no 35 de 1892), o grau de intervenção dos candidatos - vencedores e derrotados - sobre a ata a ser redigida continuava sendo muito grande. Ou seja, em que pese a mudança do Regimento Interno da Câmara Federal acerca do que se entendia por diploma, tal medida não impedia a disputa nos momentos de apuração dos votos, no âmbito dos municípios e dos estados. O fato novo era a obrigatoriedade de se enviar uma ata apenas, assinada pela maioria dos membros da junta apuradora. Mas havia sempre a possibilidade de se enviar uma segunda ata - assinada pela minoria - a qual se configuraria em contestação de resultado, a ser julgada pelas comissões de inquérito.

Os demais trâmites referentes à análise dos diplomas continuaram os mesmos. Ao fim e ao cabo, os diplomas contestados que não fossem validados pela maioria das comissões de inquérito, ou que recebessem emendas ou votos em separado, iam para votação em plenário, para cuja aprovação se demandava o quórum de metade mais um entre os presentes.

Dois novos decretos eleitorais, ambos emitidos no ano de 1902, revelariam uma maior preocupação com o controle da fraude nos processos 
eleitorais, consolidando-se uma maior participação do judiciário no processo $^{12}$. As comissões eleitorais municipais passaram por ligeiras modificações em suas composições, com previsão de membros titulares e suplentes. A ata geral de apuração da junta (redigida após a soma das autênticas enviadas pelos municípios) passou a ser assinada pelo procurador ou juiz seccional, o que antes não se encontrava previsto. Uma cópia teria que ser enviada também para o Supremo Tribunal Federal (STF), além daqueles órgãos que já as recebiam usualmente (secretarias da Câmara e do Senado e governadores). Os boletins eleitorais devidamente assinados e reconhecidos pelas autoridades notariais nos municípios poderiam substituir as autênticas, e, na falta de ambos, os apuradores deveriam recorrer ao STF ou aos juízes seccionais dos estados. Houve através desta lei uma clara tentativa de se esvaziar o poder dos executivos municipais e estaduais, retirando-lhes parte do controle sobre o processo eleitoral, repassando-o ao Judiciário.

À luz dos fatos, algumas reflexões se tornam imprescindíveis neste momento. As duas mudanças empreendidas por iniciativa de Campos Sales tinham por fim limitar a intervenção do Parlamento sobre sua própria renovação e, ao mesmo tempo, afastar dele as disputas que se davam no âmbito dos estados. Como vimos acima, boa parte da historiografia consolidou a versão que Sales esboçou em sua autobiografia, fortalecida pela obra imediatamente subsequente de Alcindo Guanabara sobre sua gestão. Desta forma, é bastante consolidada a avaliação de que a reforma regimental fora responsável pela estabilização dos conflitos que ameaçavam a República em seus primeiros anos.

Vimos até agora que a reforma tinha limites que poderiam comprometer sua eficácia. Mas para que possamos fazer uma avaliação alternativa das medidas introduzidas por Campos Sales, torna-se necessário avaliar a sua longevidade e o seu impacto real sobre o processo como um todo. É o que faremos adiante.

\section{Mudanças Posteriores à Reforma}

Dois anos depois da reforma Campos Sales, uma nova lei eleitoral mudaria o quadro político em vigor. Trata-se da lei 1269, de 15 de novembro de 1904, conhecida como "Lei Rosa e Silva". Reconhecida foi a capacidade desta lei em abrir espaços para a eleição de minorias, sendo importante destacar a introdução de mudanças propiciadas por ela. As 
mesas eleitorais passaram a ser compostas por membros do judiciário (juiz seccional e procurador da república), além dos membros da comissão de alistamento. Tais mesas se tornaram responsáveis pela indicação dos mesários. Alteraram-se igualmente os locais de apuração dos votos: a da eleição de deputados passou a ser realizada nas sedes dos distritos, e a de senadores, na capital dos estados. Participariam do processo membros dos três poderes (artigos 90 a 93, cap. 8). As juntas apuradoras se limitariam a contar os votos obtidos e não se posicionariam sobre nulidades ou inelegibilidades. No entanto, no momento de redação das atas apuradoras - que serviriam de subsídios às análises das comissões verificadoras de poderes - teriam que ser feitas menções às eventuais contestações. Dizia o parágrafo segundo, do artigo 102 do capítulo oitavo da lei em discussão: “Considera-se diploma a cópia autêntica da ata geral de apuração, assinada pela maioria dos membros da junta que tiverem funcionado. No caso de duplicata de apuração, reputar-se-à simples contestação a que for assinada pela minoria da junta".

Este parágrafo reproduzia literalmente a reforma de 1899, o que atesta que parte do Regimento Interno da Câmara funcionava na prática como uma lei eleitoral complementar. Com a lei Rosa e Silva, a reforma regimental tornava-se parte da lei eleitoral, mas reduzia-se o controle da junta sobre os resultados e ampliava-se a intervenção do judiciário sobre o processo, sem contar com a possibilidade de eleição de minorias eleitas extra chapa. Todas estas medidas contribuíam com o esvaziamento progressivo do poder das juntas apuradoras sobre o processo, base da reforma de Sales. Não surpreende que o autor da medida, que deu nome à lei, era um conhecido adversário de Sales e havia se oposto à reforma, quando de sua aprovação.

Em 1904, uma nova alteração foi feita no Regimento Interno da Câmara dos Deputados ${ }^{13}$, que viria a modificar o que vigorava a partir da reforma Campos Sales. O que antes era definido como diploma era a ata produzida pela junta eleitoral e assinada pela maioria dos presentes, sendo as duplicatas (assinadas pela minoria) qualificadas como contestações. A partir da reforma regimental de 1904, o parágrafo único do artigo 16 definia como diploma "o título ou documento que como tal for definido pela lei eleitoral vigente ao tempo em que se procedeu à eleição para a nova legislatura". Ou seja, o diploma não mais seria a ata assinada pela maioria da junta apuradora, mas aquilo que estivesse previsto como diploma na lei eleitoral em vigor. Abria-se um prece- 
dente em relação à reforma de Sales, pois a lei estava acima do Regimento da Câmara. A qualquer momento a reforma poderia perder um de seus pilares.

Pela lei em vigor no que se referia à apuração (a de 1904), caberia à junta apuradora, no caso de duplicatas, dar preferência aos resultados de eleições que tivessem ocorrido em local antes estabelecido e cuja mesa tivesse sido legalmente nomeada. Caso a junta não tivesse meios de aferir a veracidade do processo eleitoral, remeteria o problema à comissão verificadora. (artigo 99 da lei 1269). Na própria ata a ser remetida ao Congresso deveriam constar as representações, reclamações ou protestos, ilustrados pelos motivos dos pleiteantes (artigo 102). Tais procedimentos relativos à apuração já constavam de leis eleitorais anteriores e foram mantidos, mesmo enfraquecendo o poder das juntas e permitindo com que elas repassassem ao Parlamento problemas não resolvidos com suas duplicatas, recorrendo a este procedimento todas as vezes que se sentissem pressionadas. Tudo parecia retornar ao velho modelo anterior a Sales.

Poucas mudanças foram feitas posteriormente, sendo a mais importante delas de 1915. No que diz respeito ao Regimento Interno daquele ano, diferentemente dos demais, ele refundava o próprio Legislativo, a partir da inserção de procedimentos presentes na Constituição Federal e em outros marcos jurídicos existentes no próprio corpo do Regimento. Seu objetivo era o de unificar todas as disposições concernentes ao funcionamento da Câmara, que se encontravam então dispersas ${ }^{14}$. No que tange especificamente à verificação de poderes, percebem-se algumas alterações em relação ao quadro anterior. Dispondo de maior prazo para atuação (antes, 15 dias, e a partir do novo regimento, 30 dias), o direito à contestação foi mais detalhado e ampliado no artigo 17 do Regimento Interno. Deveria o contestante apresentar à comissão de inquérito uma exposição escrita dos motivos que o levavam ao pedido de impugnação de diplomas, fundamentando claramente seus argumentos. Poderia haver mais de uma contestação por candidatura, as quais seriam analisadas pelas comissões de inquérito. Da mesma forma como antes se procedia, as comissões poderiam optar pela aprovação unânime dos pareceres, pelo voto em separado ou pela proposição de emendas. Nos dois últimos casos, o debate ia a plenário. Ampliava-se também no âmbito do Parlamento o espaço de disputa e, consequentemente, de emergência de conflitos. 
O alto nível de detalhamento deste processo é significativo. Fazia parte da rotina parlamentar este debate árduo em torno de sua própria renovação. $\mathrm{O}$ candidato a deputado disputava as eleições ao longo das quatro fases: primeiro, lutava por garantir que seus eleitores fossem alistados (primeira fase, alistamento). Depois, que comparecessem às urnas e votassem em seu nome (segunda fase, eleição); em seguida, tentava intervir sobre os resultados, garantindo que seu nome fosse inserido nas atas, pressionando as juntas apuradoras (terceira fase, apuração); por fim, interferia junto às comissões verificadoras com o fim de contestar a eleição de seus concorrentes ou de se defender contra os mesmos, em que pese ter sido bem sucedido nas etapas anteriores (quarta fase, verificação).

O Regimento Interno da Câmara de Deputados instituído em $1921^{15}$ reafirmaria as responsabilidades constitucionais do Congresso. No que tange propriamente ao reconhecimento de poderes, o Regimento pouco inovou, mantendo-se as regras anteriores. Mantinha-se o espaço aberto para as contestações, garantindo-se aos pleiteantes o direito de plena defesa de seu direito ao cargo. Havia previsão para um detalhamento maior dos pareceres das comissões de inquérito, os quais deveriam conter a relação das sessões eleitorais, seus resultados, relação de candidatos inelegíveis e os que deviam ser reconhecidos. Quando a maioria dos membros da comissão de inquérito aprovasse o parecer de seu relator, o processo estaria encerrado. Se a maioria fosse contrária ao relator, um novo nome deveria ser indicado. Mantinha-se a possibilidade do voto em separado, que na prática equivaleria a um novo parecer, a ser debatido em plenário. Todo parecer sujeito à discussão em plenário teria voto nominal, o que contribuía para que as disputas se tornassem ainda mais claras (artigo 108). O processo em si era muito complexo e envolvia uma série de mecanismos de controle. $\mathrm{O}$ artigo 113 merece ser reproduzido:

Art. 113. A Câmara mandará proceder à nova eleição sempre que, no reconhecimento de poderes de seus membros, anular, por qualquer fundamento, mais de metade dos votos de candidato diplomado, ou não.

$\S 1 E$ Para esse cálculo serão deduzidos os votos de duplicatas de atas, desprezadas pela impossibilidade de se verificar qual delas é a verdadeira.

$\S 2$ E Se, ainda assim, o candidato diplomado ficar com maioria de votos sobre os demais candidatos, deverá ser reconhecido. 
§ 3.E Para a verificação da votação dos candidatos não diplomados, a Comissão de Inquérito fará, preliminarmente, a apuração, em face dos livros da eleição, enviados ao poder verificador pela Junta Apuradora.

Conforme será visto adiante, tais procedimentos implicaram em disputas árduas no âmbito do Parlamento, uma vez que a disputa eleitoral se dava também longe das urnas. O Congresso continuava a importar os conflitos para seu interior.

O amplo controle sobre o processo eleitoral talvez tenha sido responsável por garantir reduzidos índices de renovação do Parlamento, sobretudo quando comparado aos do período imperial, cuja média de renovação era de 65\% a cada nova legislatura (Santos, 2013). Em que pesem os conflitos travados no contexto das sessões preparatórias, os mecanismos de controle que impediam o acesso das minorias ao poder foram eficazes.

Um novo Regimento Interno foi aprovado em 1928. Através dele percebe-se que o processo continuava complexo e demorado. O parágrafo segundo de artigo 26 ilustra bem a situação. Diz ele: "Os membros das comissões de inquérito, que não tiverem sido reconhecidos até a instalação do Congresso Nacional, serão substituídos na primeira sessão ordinária da Câmara". Isso comprova que as sessões preparatórias não encerravam as discussões sobre a composição do Parlamento, as quais eram prorrogadas até o início efetivo das sessões.

Tal situação refletia a existência de problemas na base do processo eleitoral. A verificação de poderes se processava a partir da análise do material produzido pelas juntas apuradoras, que nem sempre funcionavam sob o rigor da lei. Uma situação prevista pelo regimento ilustra bem o nível de desorganização do processo: "Quando a junta apuradora não expedir diplomas, ou quando os expedidos forem julgados ilegais, os candidatos que se apresentarem, serão considerados, a um só tempo, contestantes e, reciprocamente, contestados" (parágrafo 6, artigo 31). Ou seja, mesmo após as tentativas estabilizadoras empreendidas por Campos Sales, as juntas eleitorais continuavam a enviar resultados díspares para o Congresso, delegando a ele, em última instância, a resolução dos conflitos intraelitistas que se davam na base. Não fosse isto, o Regimento Interno não precisaria ter incluído esta previsão.

O penúltimo regimento aprovado antes da Revolução de 1930 foi o de $1929^{16}$, que demonstra um alto nível de desorganização do processo. 
Seu décimo terceiro artigo prevê a solução para uma situação inusitada: caso o candidato viesse a ser eleito por dois distritos eleitorais distintos, obtendo desta forma dois mandatos, deveria escolher apenas um entre eles ${ }^{17}$.

Como foi possível notar, as reformas empreendidas por Sales foram parcialmente alteradas mais tarde, no sentido de aperfeiçoar os mecanismos de funcionamento do processo de verificação. Pelas últimas alterações percebe-se que as contestações e o envio de duplicatas continuavam a ocorrer. Se o fim último da política dos estados era impedir que tais conflitos se expressassem no Parlamento, não houve êxito. Mais de uma ata continuava a ser enviada, a da minoria, fazendo com que as contestações continuassem a fazer parte da rotina do legislativo. Para que um candidato derrotado nas urnas pudesse ter seus resultados reavaliados, bastava conseguir de um membro da junta apuradora o apoio que lhe garantisse um resultado favorável, viabilizando sua contestação. Mas este é um assunto para o próximo item.

\section{Avaliando o Impacto da Reforma}

Entre os dois procedimentos criados pela reforma, em nosso entendimento, o primeiro era o mais expressivo, já que o segundo pouco mudara a rotina dos reconhecimentos. O primeiro, relativo a quem deveria presidir as sessões preparatórias e como deveriam ser compostas as comissões, garantia maior estabilidade durante a fase final da disputa eleitoral. O segundo procedimento, relativo à vinculação do diploma às atas eleitorais, dependeria não da Câmara, mas de uma aquiescência prévia à reforma por parte dos chefes municipais e estaduais, o que era muito difícil de ser obtido, em um modelo de federalismo descentralizado e desigual. Tanto é que as duplicatas e contestações continuaram a chegar na secretaria da Câmara, que teve que manter a mesma rotina de realizar uma "segunda apuração" em suas comissões de inquérito.

Em geral, a historiografia acerca do Estado oligárquico republicano antes referenciada atribuiu um papel maior ao processo de verificação de poderes do que efetivamente pesquisas empíricas mais recentes têm revelado. A verificação era uma etapa final de um longo processo, que se iniciava no município. As leis eleitorais definiam o município como o local de votação, o estado como o local de apuração e a Federação como o local do reconhecimento de poderes. Os entes municipais, 
estaduais e federal participavam do processo de progressiva depuração das candidaturas. Cada um deles tinha sua reserva de poder. Uma avaliação apressada pode pressupor um equilíbrio de poder entre as três esferas. Afinal, na primeira instância, a municipal, controlava-se o voto do cidadão; na segunda, a estadual, controlava-se as atas que seriam enviadas ao Parlamento; na terceira instância, a do próprio Parlamento, fazia-se o controle final e definitivo, ao diplomar-se ou não um candidato.

Em nosso entendimento, esta distribuição de poderes era bastante desigual. O elo mais fraco era o municipal, uma vez que os resultados obtidos nas seções eleitorais e registrados em atas enviadas às capitais dos estados poderiam ser alterados no momento da soma dos votos totais do estado. A instância estadual era, ao nosso ver, a que maior controle tinha sobre o processo, na medida em que as juntas apuradoras eram responsáveis pela soma total de votos e pelo envio da ata com os eleitos para o Parlamento. Para que as comissões verificadoras negassem um diploma, ao degolar um candidato era necessário que o mesmo fosse contestado ou que os estados enviassem duplicatas eleitorais. Em oligarquias com razoável grau de controle de suas dissidências internas, ambas as situações eram raras, conferindo nesses casos pouco poder de controle ao terceiro escrutínio (o do Parlamento). Outrossim, em oligarquias com maior grau de animosidade interna, os resultados eleitorais escapavam do controle estadual, conferindo ao Parlamento um poder maior de intervenção sobre os resultados finais.

Como visto, o processo de verificação de poderes era muito complexo. As degolas que dele resultavam causavam muito desgaste ao sistema, comprometendo sua estabilidade. Recorria-se a este expediente só em último caso, ou seja, quando estavam esgotadas todas as possibilidades de consenso interno no seio das oligarquias estaduais.

Um trabalho relativamente desconhecido, por não ter sido publicado, de Maria Carmem C. Magalhães (1986) trouxe dados inéditos acerca do processo de verificação com base em levantamentos realizados acerca do volume das mesmas. Baseando-se nos diários e anais parlamentares, regimentos internos da Câmara e em alguns pareceres das comissões de inquérito, a autora identificou que o volume de degolados era muito menor do que se pensava.

A partir dos dados apresentados pela autora, montamos uma tabela comparativa em que constam na primeira coluna o número da legisla- 
tura, na segunda, o período de sua gestão, na terceira, quem ocupava a Presidência da República na ocasião, e na quarta coluna, o percentual dos não reconhecimentos em relação ao número total encontrado pela autora ao longo de todo o período ${ }^{18}$. Os resultados são os seguintes:

Tabela 1

Relação do Número de Deputados Não Reconhecidos por Legislatura

\begin{tabular}{l|c|l|c|c}
\hline Legislaturas & Período & \multicolumn{1}{|c|}{ Presidências } & No de Degolas & $\mathbf{\%}$ \\
\hline 23 & $1894-1896$ & Floriano/Prudente de Moraes & 1 & 0,33 \\
24 & $1897-1899$ & Prudente/Campos Sales & 17 & 5,65 \\
$\mathbf{2 5}$ & $\mathbf{1 9 0 0 - 1 9 0 2}$ & Campos Sales & 74 & $\mathbf{2 4 , 5 8}$ \\
26 & $1903-1905$ & Rodrigues Alves & 12 & 3,99 \\
27 & $1906-1908$ & R. Alves/A. Penna & 17 & 5,65 \\
28 & $1909-1911$ & N. Peçanha/Hermes da Fonseca & 12 & 3,99 \\
$\mathbf{2 9}$ & $\mathbf{1 9 1 2 - 1 9 1 4}$ & Hermes da Fonseca & $\mathbf{9 1}$ & $\mathbf{3 0 , 2 3}$ \\
$\mathbf{3 0}$ & $\mathbf{1 9 1 5 - 1 9 1 7}$ & Wenceslau Brás & $\mathbf{6 3}$ & $\mathbf{2 0 , 9 3}$ \\
31 & $1918-1920$ & Wenceslau/Epitácio & 5 & 0,99 \\
32 & $1921-1923$ & Epitácio/Bernardes & 6 & 1,66 \\
33 & $1924-1926$ & Bernardes & 0 & 1,99 \\
34 & $1927-1929$ & Washington Luiz & 0 & 0,00 \\
35 & $1930-1932$ & Júlio Prestes/Vargas & $\mathbf{3 0 1}$ & $\mathbf{1 0 0 , 0}$ \\
\hline \multicolumn{2}{|l}{ Total } \\
\hline
\end{tabular}

Fonte: Tabela montada com base em dados disponibilizados por Magalhães (1986:76).

A primeira constatação que a tabela nos proporciona é que o número de degolados era muito pouco significativo para o conjunto de deputados, sendo, ao longo de todo o período, inferior a $9,84 \%$ do tota ${ }^{19}$. Pensava-se antes que a verificação de poderes fosse a guilhotina final, capaz de alterar decisões previamente tomadas por eleitores e juntas eleitorais. No entanto, estes números revelam que o controle sobre as eleições se dava muito mais no âmbito dos municípios e estados do que no próprio Parlamento, antes ou depois da reforma de Campos Sales. Tendo em vista o grau de complexidade que envolvia o processo, é provável que a Câmara se recusasse a alterar resultados que vinham da base com o fim de manter homogêneo o corpo legislativo. Nota-se que houve um impacto imediato sobre o número de degolas após a aprovação da reforma, impacto este limitado ao período, voltando à normalidade até o governo Hermes.

Interessante destacar que Magalhães (1986:62) subestimou o papel da reforma de Sales sobre os resultados dos processos de verificação de 
poderes. Segundo a autora a reforma foi apenas um "arranjo casuístico da cúpula política para atender interesses governamentais do momento", com o que concordamos plenamente.

Os levantamentos mais recentes acerca da verificação de poderes (Ricci e Zulini, 2012:513) englobaram, além do número de degolas, os dados relativos às contestações realizadas. Diferentemente de Magalhães, os autores encontraram para o mesmo período 260 degolas, sendo 196 relativas às duplicatas eleitorais e 64 às contestações. Para o período foram encontradas um total de 486 contestações. O que se observa, a par do baixo número de depurações, é que ambas as estratégias eram usadas como meios de alterar resultados eleitorais obtidos após a apuração das juntas nos estados. De acordo com os dados dos autores, nas eleições de 1900 (após a reforma Campos Sales) foram degolados 78 deputados (30\% do total), na de 1912, 40 deputados (15,38\%), e na de 1915, 62 deputados, ou seja, $23,84 \%$ do total de deputados. O percentual médio foi de $9,4 \%$ de não reconhecimentos, número muito próximo ao encontrado por Magalhães. Em todos os levantamentos disponíveis, a maior parte das degolas ocorreu nos anos de 1900, 1912 e 1915, tal como havia verificado Magalhães.

Há pequenas divergências entre os autores na atribuição de motivos para o aumento do número de degolados nos três períodos distintos e para a ausência de degolas nas últimas duas legislaturas. Na visão de Magalhães (1986:95-101), o alto número de degolas em 1900 se explica pela disputa antes existente entre concentrados e republicanos que se fortalecia na tentativa de controle do novo governo. Nas eleições de 1912, o alto número é explicado como um reflexo no Parlamento das cisões causadas pela introdução da política de salvações pelo governo Hermes da Fonseca. Nas eleições de 1915, o mesmo fenômeno esteve envolvido, ou seja, os elementos expurgados por Hermes tentariam a retomada de seu espaço no Parlamento após o fim de seu mandato. Em relação às ausências de degolas em 1927 e 1930, a própria autora se surpreendeu. Destaca que a comissão de inquérito incumbida da análise das atas provenientes de Minas Gerais relatou o não recebimento das mesmas. Para que o estado não ficasse sem representação, procederam à apuração dos sete distritos eleitorais, o que foi feito entre 1 e 11 de maio de 1930. 14 deputados em 37 foram agregados à bancada a partir de emendas parlamentares aprovadas em plenário. Estes deputados agregados eram ligados a Washington Luís. A autora reconhece que es- 
tudos adicionais precisam ser feitos para que esta questão se esclareça. Quanto a 1927, a razão das ausências não foi esclarecida pela autora.

Na visão de Ricci e Zulini (2012:507, 516-518), os altos números e a ausência de degolas nos períodos citados obedecem a uma lógica por eles defendida acerca do papel das verificações de poderes. Para os autores, elas funcionavam quando as bases oligárquicas regionais não tinham êxito na resolução de seus conflitos políticos. Desta forma, a explicação para os baixos números deve ser encontrada nas análises das políticas internas dos municípios e estados, mas, ao mesmo tempo, admitem a possibilidade de terem sido resultantes de punições impetradas por vencedores aos vencidos. Na ausência deste quadro em 1900, atribuem o aumento do número às intervenções de Campos Sales, e exemplificam com o caso de Mato Grosso. Para os casos de 1912 e 1915, retomam a mesma hipótese de Magalhães. Sobre as ausências de dados em 1927 e 1930, os autores também as atribuem a conflitos internos dos estados.

Retomando ambos os levantamentos acima, é possível afirmar que após a reforma de 1899 o número de depurações aumentou em quase três vezes, obrigando as comissões de inquérito a realizar mais degolas do que o normal. O mesmo fato se repetiria nos governos de Hermes e Wenceslau, o que, para os fins deste artigo, não nos interessa tratar. Concentrando por ora as análises no primeiro momento dos três citados, cabe perguntar de que maneira a reforma regimental teria contribuído para o aumento do número de duplicatas e contestações e, por conseguinte, o de não reconhecimentos? Provavelmente, os grupos que se encontravam fora do Parlamento viram na reforma uma nova janela de oportunidades. Bastava para isto que obtivessem durante a apuração resultados duplicados, ou que fizessem contestações de resultados já apurados. Conforme previa a lei, ao obter-se uma ata assinada pela minoria da junta apuradora, o candidato teria o direito de ter sua votação avaliada pelas comissões de inquérito, sob o caráter de contestação. A reforma, ao invés de inibir os conflitos internos nos estados acabou por acirrá-los, possibilitando nova oportunidade aos derrotados de serem eleitos.

Se o que Sales queria evitar com a reforma era a instabilidade derivada da disputa entre diplomas verdadeiros e falsos, o tiro saiu pela culatra: a disputa aumentou. Como se vê pelos dados antes relatados, nas três legislaturas seguintes o número de degolas voltou à normalidade, bem 
como o número de contestações, o que também atesta nosso argumento de que o impacto da reforma Sales foi limitado.

É interessante observar a relação entre as degolas e as bancadas dos estados nelas envolvidos. Entre as 21 unidades federativas, Bahia e Rio de Janeiro foram as maiores vítimas de degolas, com 68 e 54 deputados degolados respectivamente, num universo de 301 (Magalhães, 1986:76).

Tendo em vista que eram bancadas grandes, fizemos um levantamento que levasse em conta a proporcionalidade, uma vez que os números absolutos não revelam o real impacto das degolas em estados com grandes e pequenas bancadas. Ainda assim, o Rio de Janeiro e a Bahia foram os estados que mais sofreram degolas, seguidos por Piauí e Amazonas. Os dois primeiros estados eram reconhecidamente os que mais dissidências internas possuíam, o que repercutia diretamente na proliferação de duplicatas e no não reconhecimento de quase um quarto de suas bancadas. Entre os grandes estados, o Rio Grande do Sul, Minas Gerais e São Paulo foram os mais estáveis, garantia de poder que exerciam sobre o regime, o que já foi ratificado por outras análises que fizemos (Viscardi, 2012).

A tabela a seguir ilustra o panorama de forma mais ampla:

Pode-se aventar que a ampliação do número de degolas pós-reforma se deu com o fim de garantir que as oposições fossem afastadas do poder, assegurando-se a composição de um Parlamento mais homogêneo e compatível com as situações estaduais. É conhecida a perspectiva que afirma que após a reforma de 1899 ocorreu uma consolidação das mesmas lideranças, impedindo-se a entrada de minorias no Parlamento. O pacto construído entre a Presidência da República e os governadores dos estados teria imposto novos obstáculos à renovação do Parlamento, que antes se dava sem controle.

Se analisarmos os índices de renovação do Parlamento ao longo da Primeira República, perceberemos que o impacto da reforma de 1899 foi inexpressivo, ou seja, em nada alterou o índice de renovação em vigor, em geral relativamente baixo. É o que se observa pela tabela abaixo:

Como se pode notar, houve uma expressiva renovação da Câmara em 1894, o que pode ser explicado pela mudança do controle político do novo regime, o qual passou para mãos civis. Após este período, o índice de renovação permaneceu o mesmo, próximo à média geral. O que 
Tabela 2

Relação entre os Percentuais de Degola por Estado

\begin{tabular}{|c|c|c|c|}
\hline Estado & $\begin{array}{c}\text { Bancada } \\
\text { (№ de Deputados X 13 Legislaturas) } \\
\end{array}$ & Degolados & $\%$ \\
\hline AM & 52 & 11 & 21,15 \\
\hline ES & 52 & 8 & 15,38 \\
\hline PR & 52 & 4 & 7,69 \\
\hline MT & 52 & 2 & 3,84 \\
\hline $\mathrm{RN}$ & 52 & 1 & 1,92 \\
\hline SC & 52 & 4 & 7,69 \\
\hline GO & 52 & 8 & 15,38 \\
\hline PI & 52 & 11 & 21,15 \\
\hline SE & 52 & 8 & 15,38 \\
\hline PB & 65 & 11 & 16,92 \\
\hline $\mathrm{AL}$ & 78 & 12 & 15,38 \\
\hline MA & 91 & 5 & 5,49 \\
\hline PA & 91 & 6 & 6,59 \\
\hline $\mathrm{CE}$ & 130 & 22 & 16,92 \\
\hline DF & 130 & 23 & 17,69 \\
\hline RS & 208 & 3 & 1,44 \\
\hline RJ & 221 & 54 & 24,43 \\
\hline PE & 221 & 12 & 5,42 \\
\hline SP & 286 & 12 & 4,19 \\
\hline BA & 286 & 68 & 23,77 \\
\hline MG & 481 & 16 & 3,32 \\
\hline Total & 2.756 & 301 & 10,92 \\
\hline
\end{tabular}

Fonte: Tabela montada com dados extraídos de Magalhães (1986:76-80).

queremos destacar é que as diferentes legislaturas, mesmo após a reforma do regimento de 1899, mantiveram-se com índices muito próximos, ou seja, as alterações feitas por Campos Sales pouco alteraram a dinâmica de renovação da Câmara. Se os deputados eleitos passaram a estar sob o controle dos governadores, conforme era objetivo da política dos estados, já o estavam antes, na medida em que os nomes pouco mudaram. Se os deputados eleitos após a reforma de Sales foram majoritariamente os mesmos, seu intuito - que era o de compor uma câmara a partir das situações dos estados-membros da Federação - não precisaria ter sido levado à frente ou, uma vez realizado, não surtira os efeitos desejados. 
Tabela 3

Taxa de Renovação Bruta de Deputados no Brasil

\begin{tabular}{l|c|c}
\hline Legislaturas & Período & \% de Renovação \\
\hline 22 & $1891-1893$ & 17 \\
$\mathbf{2 3}$ & $\mathbf{1 8 9 4 - 1 8 9 6}$ & $\mathbf{6 3}$ \\
$\mathbf{2 4}$ & $\mathbf{1 8 9 7 - 1 8 9 9}$ & $\mathbf{4 4}$ \\
$\mathbf{2 5}$ & $\mathbf{1 9 0 0 - 1 9 0 2}$ & $\mathbf{4 6}$ \\
$\mathbf{2 6}$ & $\mathbf{1 9 0 3 - 1 9 0 5}$ & $\mathbf{4 0}$ \\
27 & $1906-1908$ & 42 \\
28 & $1909-1911$ & 40 \\
29 & $1912-1914$ & 48 \\
30 & $1915-1917$ & 46 \\
31 & $1918-1920$ & 41 \\
32 & $1921-1923$ & 41 \\
33 & $1924-1926$ & 43 \\
34 & $1926-1928$ & 41 \\
35 & $1929-1930$ & 30 \\
\hline Média & & 38 \\
\hline
\end{tabular}

Fonte: Santos (2013:11 e 16).

As duas tabelas também informam que as alterações propostas por Sales só tiveram impacto durante a $25^{a}$ legislatura, ou seja, não contribuíram para a estabilização do regime como um todo. Com base em tais prerrogativas, é preciso identificar quais outros mecanismos funcionavam como estabilizadores do regime ou admitir que o regime era mais instável do que se supunha.

\section{CONSIDERAÇÕES FINAIS}

Com base no que foi visto, a tese do caráter estabilizador da República resultante da política dos estados, bastante consolidada, merece ser contestada. Sem diminuir por completo a importância das duas alterações regimentais no funcionamento da Câmara Federal, elas não teriam sido suficientes para estabilizar conflitos intraelitistas que se davam por toda a esfera política nacional. Quando muito, teriam pacificado uma das câmaras do Parlamento, em suas relações com os governadores, mas não a política de forma mais ampla. Muito menos representariam um consenso sobre os rumos do novo regime, em torno dos quais estariam todos reunidos. E não seriam suficientes para aplacar os anseios de inserção no mercado político por parte de setores 
emergentes. Se concordarmos com o diagnóstico, devemos concluir que o antibiótico foi reconhecidamente de baixo espectro.

Partindo desse pressuposto, duas conclusões são possíveis: ou a reforma não foi responsável sozinha pela estabilização do regime, ou não ocorreu de fato uma estabilização do mesmo. A aceitação das duas premissas a um só tempo, o que também é possível, nos leva a admitir a possibilidade da Primeira República ter sido mais instável politicamente do que os seus estudiosos admitem ou de que sua relativa estabilidade tenha resultado de um conjunto de fatores que não se limitaram à reforma de Sales. Acreditamos que ambas as opções estejam corretas.

Desta forma, é possível admitir que os conflitos da primeira década foram naturais a um processo de implantação de mudanças e que seus momentos mais graves já haviam sido superados no segundo biênio do mandato de Prudente de Morais, o que lhe possibilitou, inclusive, fazer seu sucessor sem nenhum trauma político, numa das eleições mais facilmente vencidas pela situação. Lembremos que os contemporâneos do regime atribuíram a Prudente, e não a Campos Sales, o título de pacificador da República. Explica-se, por esta razão, a aprovação incondicional por parte do Parlamento e da classe política em geral, antes dividida em duas facções em luta, que Sales teve assim que assumiu o governo. Ou seja, quando Sales assumiu, o próprio Congresso já estava pacificado e se reuniu em torno dele, aprovando sem hesitação as reformas propostas.

É igualmente possível admitir que vencidas as dificuldades iniciais, a República aprendeu a conviver com as dissidências internas, conciliando-nas na maior parte das vezes através de mecanismos múltiplos e complexos, que não se resumiam a uma mudança regimental.

Não se trata de identificar quem de fato pacificou o regime - discussão muito pouco interessante para a historiografia como um todo - mas de reconhecer que a complexidade das lutas então travadas dificilmente teria sido resolvida por duas mudanças regimentais em uma das Câmaras de um dos três poderes instituídos, em uma só instância de poder, a federal. O problema era demasiadamente complexo para soluções tão simples, por mais miraculosas e geniais que pareçam ter sido.

Como visto a partir da análise dos reconhecimentos e degolas antes e depois da implementação das mudanças, foi possível identificar que, 
comparativamente, a reforma regimental pouco alterou o funcionamento da verificação de poderes, fazendo com que o número de degolados variasse pouco após a instituição do novo método de Sales. No geral, com exceções pontuais, esse número era pequeno, comprovando nossa assertiva de que o remédio foi fraco ou o doente não estava assim tão mal como antes pensávamos. Ou que vencida a sua primeira década de vida, o paciente tornou-se imune a uma série de ameaças, dispensando a aplicação de fórmulas miraculosas de prolongamento de sua vida.

$\mathrm{O}$ esforço que as elites empreenderam na tentativa de regulamentar ambos os processos - o eleitoral e o de verificação - não foi suficiente para a garantia da ordem e para o apaziguamento dos conflitos, em que pesem os inúmeros regulamentos. A possibilidade prevista pelos regimentos de conferir aos deputados o direito de proporem emendas aos pareceres das comissões de inquérito tornava o plenário uma arena de interesses divergentes e de luta pela hegemonia de grupos.

Segundo narra Guanabara, na ausência de partidos políticos nacionais ou mesmo de facções rivais, a sucessão de Sales se deu de forma tranquila. Numa convenção ocorrida em setembro de 1901 que contou com a participação de 38 delegados, 37 aprovaram a indicação da chapa Rodrigues Alves-Silviano Brandão, lançada por Sales. A chapa havia resultado de um acordo ocorrido em reunião anterior, no mês de agosto, na qual participaram 19 representantes dos 21 estados. Os dois estados a não comparecer - Pernambuco e Maranhão - mostravam o tamanho da oposição (Guanabara:1983:90-92).

(Recebido para publicação em fevereiro de 2015)

(Reapresentado em abril de 2016) (Aprovado para publicação em julho de 2016) 


\section{NOTAS}

1. Aqui nos referimos a diversos trabalhos, e o que lhe foi mais contemporâneo foi a biografia escrita em 1896 por Antônio Joaquim Ribas, quando Campos Sales era ainda senador. O autor havia sido seu professor na Faculdade de Direito de São Paulo (Ribas, 1983:7). Foi de Alcindo Guanabara (1983), político e jornalista do Distrito Federal, que mantinha relações muito próximas a Sales, a autoria de uma segunda obra contemporânea sobre o seu governo, publicada em 1902, imediatamente após o seu término. Em 1928, Tobias Monteiro (2005) publicou um trabalho em que narrava sua viagem com Campos Sales à Europa em 1898, na condição de jornalista do Jornal do Comércio, quando da negociação do funding loan. O autor já havia publicado uma biografia oito anos antes sobre ele (Monteiro, 1920). Na década de 1940 foram publicados mais três livros sobre Campos Sales, por pessoas que a ele estiveram ligadas direta ou indiretamente. $\mathrm{O}$ primeiro deles, escrito pelo deputado federal e filho de Rodrigues Alves, Francisco de Paula R. Alves Filho (1940); o segundo, pelo seu ex-ministro da Relações Exteriores, Olyntho Magalhães (1941), em comemoração ao seu centenário; e o terceiro pelo seu próprio filho, Sales Júnior (1944), todos com base em documentos reunidos pelos próprios autores acerca da trajetória pessoal e política de Sales.

2. Para uma análise das medidas econômicas implantadas pelo governo de Sales, tendo à frente o Ministro das Finanças Joaquim Murtinho, ver: Franco (1989), Fritsch (1989) e Abreu (2002), entre outros.

3. Acreditamos que uma análise deste mesmo processo no Senado se faz necessária. No entanto, tal pesquisa demandaria um esforço muito maior, que não nos foi possível empreender, além do fato de que tal análise ultrapassaria os limites de um capítulo.

4. Há vasto material disponível sobre os conflitos que dividiam o Brasil nos dez primeiros anos do novo regime. Destacamos os seguintes: Franco (1993), Janotti (1986), Levine (1995), Penna (1997).

5. Os regimentos analisados foram: 1891, 1899, 1901, 1903 e o de 1904. Foi analisado também o Regimento de 1857 para fazermos uma comparação com o período anterior ao republicano.

6. Regimento Interno da Câmara de Deputados. Diário do Congresso, 19 de junho de 1891, artigos de 1 a 4.

7. Após reforma regimental em 1904, o número de comissões de inquérito foi ampliado de cinco para seis.

8. Artigo 46 da lei $n \mathrm{o} 35$ de 26 de janeiro de 1892 (Jobim e Porto, 1996:418).

9. Decreto $\mathrm{n} \mathbf{0} 1.542$, de 1 de setembro de 1893.

10. Ojacobinismo foi um movimento urbano formado por militares, funcionários públicos e profissionais liberais que se aglutinavam em torno da liderança política de Floriano Peixoto. Defendiam o nacionalismo, o intervencionismo estatal e a permanência dos militares no controle do regime republicano. Eram lusófobos e acreditavam que a república estivesse sempre em perigo. No Parlamento, tinham como sua maior liderança o paulista Francisco Glicério. No governo, o vice-presidente Manoel Vitorino. Acerca do tema ver Janotti, 1986.

11. Regimento Interno da Câmara de deputados. Rio de Janeiro: Imprensa Nacional, 1901. Mudanças até 30 de outubro de 1899 mais aditamentos de 1900. 
12. Aqui nos referimos ao decreto 4616 de 28 de outubro de 1902 e ao 4695 de 11 de dezembro do mesmo ano.

13. Diário do Congresso Nacional, 28 de dezembro de 1904.

14. Regimento Interno da Câmara de Deputados. Rio de Janeiro: Imprensa Nacional, 1915.

15. Regimento Interno e Constituição da República com Índices Sistemáticos. Rio de Janeiro, Imprensa Nacional, 1921.

16. Regimento Interno e Constituição da República. Rio de Janeiro, Imprensa Nacional, 1929.

17. O último regimento em nada alterou o processo em curso. Regimento Interno e Constituição da República. Acrescido da lei 27 de 1892: regula julgamento de presidentes e ministros, da lei 30 de 1892: regula crime de responsabilidade do Presidente da República e da lei 2511 de 1911: Tomada de contas. Rio de Janeiro, Imprensa Nacional, 1930.

18. Chama-nos a atenção neste levantamento a ausência de degolas ocorridas nas eleições de 1929, quando deixaram de ser reconhecidos todos os deputados da bancada da Paraíba (cinco) e 14 deputados mineiros. A ausência desses dados altera os resultados obtidos para mais.

19. Para este resultado, a autora (Magalhães, 1986:95) calculou o percentual que representava 301 degolas num total de 3.057 diplomas (212 deputados x 13 legislaturas + 301). 


\section{REFERÊNCIAS BIBLIOGRÁFICAS}

ABREU, Marcelo P. (2002), “Os Funding Loans Brasileiros-1898-1931”. Pesquisa e Planejamento Econômico, vol. 32, no 3, pp. 515-540.

ALVES FILHO, Francisco Rodrigues. (1940), Campos Sales. São Paulo, Cultura do Brasil.

BACKES, Ana Luiza. (2006), Fundamentos da Ordem Republicana: Repensando o Pacto Campos Sales. Brasília, Plenarium.

CARDOSO, Fernando Henrique. (1975), “Dos Governos Militares a Prudente-Campos Sales", in B. Fausto (org.), História Geral da Civilização Brasileira: O Brasil Republicano: Estrutura de Poder e Economia. São Paulo, Difel.

CARONE, Edgar. (1983), A República Velha: Evolução Política. 4a ed. São Paulo, Difel. . (1988), A República Velha: Instituições e Classes Sociais. 5ạ ed. São Paulo, Difel.

FRANCO, Afonso A. de M. (1955), Um Estadista na República. Rio de Janeiro, José Olympio.

FRANCO, Gustavo B. (1989), “A Primeira Década Republicana”, in M. de P. Abreu (org.), A Ordem do Progresso: Cem Anos de Política Econômica Republicana (1889-1989). Rio de Janeiro, Campus, pp. 11-30.

FRANCO, Sérgio da Costa. (1993), A Guerra Civil de 1893. Porto Alegre, Editora UFRGS.

FRITSCH, Winston. (1989), “Apogeu e Crise na Primeira República: 1900-1930”, in M. de P. Abreu (org.), A Ordem do Progresso: Cem Anos de Política Econômica Republicana (1889-1989). Rio de Janeiro, Campus, pp. 31-72.

GUANABARA, Alcindo. (1983), A Presidência Campos Sales. Brasília, UnB.

IGLÉSIAS, Francisco. (1993), Trajetória Política do Brasil (1500-1964). São Paulo, Companhia das Letras.

JANOTTI, Maria de L. M. (1986), Os Subversivos da República. São Paulo, Brasiliense.

JOBIM, Nelson; PORTO, Walter C. (1996), Legislação Eleitoral no Brasil: Do Século XVI aos Nossos Dias. Brasília, Senado Federal, volume 1.

LEAL, Victor Nunes. (1993), Coronelismo, Enxada e Voto: O Município e o Regime Representativo no Brasil. 6a ed. São Paulo, Alfa-Ômega.

LESSA, Renato. (1988), A Invenção Republicana. Rio de Janeiro, Vértice.

LEVINE, Robert M. (1995), O Sertão Prometido: O Massacre de Canudos. São Paulo, EDUSP.

MAGALHÃES, Maria Carmem C. (1986), O Mecanismo das "Comissões Verificadoras" de Poderes: Estabilidade e Dominação Política, 1894-1930. Dissertação (Mestrado em História), Universidade de Brasília, Brasília.

MAGALHÃES, Olyntho de. (1941), Centenário do Presidente Campos Sales: Comentários e Documentos sobre Alguns Episódios de seu Governo pelo Ministro das Relações Exteriores de 1898 a 1902. Rio de Janeiro, Irmãos Pongetti.

MENDONÇA, Sônia R. de. (1990), “Estado e Sociedade: A Consolidação da República Oligárquica”, in M. Y. Linhares et al. (orgs.), História Geral do Brasil. 4a ed. Rio de Janeiro, Campus. 


\section{Cláudia Maria R. Viscardi}

MONTEIRO, Tobias. (1920), O Presidente Campos Sales. Rio de Janeiro, Briguet. (2005), O Presidente Campos Sales na Europa. Brasília, Senado Federal.

PENNA, Lincoln Abreu. (1989), Uma História da República. Rio de Janeiro, Nova Fronteira.

. (1997), O Progresso da Ordem: O Florianismo e a Construção da República. Rio de Janeiro, Sette Letras.

RIBAS, Antônio J. (1983), Perfil Biográfico do Dr. Manoel Ferraz de Campos Sales. Brasília, Editora da UnB.

RICCI, Paolo; ZULINI, Jaqueline. (2012), “Beheading, Rule Manipulation and Fraud: The Approval of Election Results in Brazil, 1894-1930". Journal of Latin American Studies, vol. 44, no 3, pp. 495-521.

SALES JUNIOR, Antonio Carlos de. (1944), O Idealismo Republicano de Campos Sales. Rio de Janeiro, Zelio Valverde.

SALLES, Manuel Ferraz de Campos. (1983), Da Propaganda à Presidência. Brasília, Editora da UnB.

SANTOS, Wanderley G. dos. (2013), "O Sistema Oligárquico Representativo da Primeira República”. DADOS - Revista de Ciências Sociais, vol. 56, no 1, pp. 9-37.

SILVA, Hélio. (1975), História da República Brasileira. São Paulo, Editora 3, vol. 2.

SOUZA, Maria do Carmo C. de. (1985), “O Processo Político-partidário na Primeira República”, in C. G. Mota (org.), Brasil em Perspectiva. 15a ed. São Paulo, Difel.

VISCARDI, Cláudia M. R. (2012), Teatro das Oligarquias: Uma Revisão da Política do Cafécom Leite. 2a ed. Belo Horizonte, Fino Traço.

WIRTH, John. (1982), O Fiel da Balança: Minas Gerais na Federação Brasileira (1889-1937). Rio de Janeiro, Paz e Terra. 


\section{RESUMO \\ O Federalismo como Experiência: Campos Sales e as Tentativas de Estabilização da República}

O artigo propõe uma interpretação alternativa à política dos estados, estabelecida por Campos Sales quando esteve à frente da Presidência da República brasileira. A partir da análise da dinâmica do processo de verificação de poderes, das leis eleitorais e das memórias construídas sobre o processo, procuramos comprovar que o impacto da reforma limitou-se ao seu quatriênio (1898-1902), o que induz à revisão de uma tese bastante consolidada, acerca do estado oligárquico na Primeira República, qual seja, a de que a política por ele proposta e implantada tenha sido responsável pela estabilização dos conflitos políticos que opunham o Executivo ao Parlamento. Deste modo, defende-se a hipótese de que os conflitos antes existentes permaneceram e que as mudanças regimentais propostas tenham tido pouco impacto sobre a estabilização dos mesmos.

Palavras-chave: política dos estados; Campos Sales; verificação de poderes; eleições; estabilidade política

\section{ABSTRACT \\ Federalism as an Experience: Campos Sales and Attempts to Stabilize the Brazilian Republic}

This article suggests an alternative interpretation of the politica dos estados or politica dos governadores [politics of the governors] established by Campos Sales during his time as President of Brazil. By means of an analysis of the dynamics of the procedure for the verification of credentials, of the electoral laws, and of the memories shaped in the process, we seek to prove that the impact of the reform was limited to Sales' term in office from 1898-1902, prompting us to challenge the consolidated argument on the oligarchy in the First Brazilian Republic, which claims that the policy Sales proposed and implemented was responsible for stabilizing the political conflicts that placed the executive and parliament in opposition. The article thus demonstrates the persistence of previously existing conflicts, and suggests that the changes proposed to the regime did little to stabilize such conflicts.

Key words: politica dos estados/governadores [politics of the governors]; Campos Sales; verification of credentials; elections; political stability 


\section{RÉSUMÉ \\ Le fédéralisme comme expérience : Campos Sales et les tentatives de stabilisation de la République}

Cet article propose une interprétation alternative de la politique des États établie par Campos Sales lorsqu'il était à la tête de la République brésilienne. À partir de l'analyse dynamique de la vérification des pouvoirs, des lois électorales et des mémoires construites autour du processus, nous avons voulu prouver que l'impact de la réforme s'est limité au mandat 1898-1902, ce qui impose une révision de la thèse assez diffusée relative à l'État oligarchique de la Première République et selon laquelle la politique mise en œuvre par celle-ci aurait permis la stabilisation des conflits politiques qui opposaient l'Exécutif au Parlement. Nous défendrons ainsi l'hypothèse de ce que les conflits déjà existants se sont maintenus et que les changements régimentaires proposés ont eu peu d'impact sur la stabilisation desdits conflits.

Mots-clés: politique des États; Campos Sales; vérification des pouvoirs; élections; stabilité politique

\section{RESUMEN \\ El Federalismo como Experiencia: Campos Sales y los Intentos de Estabilización de la República}

El artículo propone una interpretación alternativa a la política de los Estados, establecida por Campos Sales cuando estuvo al frente de la presidencia de la República brasileña. A partir del análisis de la dinámica del proceso de verificación de poderes, de las leyes electorales y las memorias construidas sobre el proceso, tratamos de comprobar que el impacto de la reforma se limitó al cuatrienio (1898-1902), lo que induce a la revisión de una tesis bastante consolidada acerca del estado oligárquico en la Primera República, la de que la política por él propuesta e implantada haya sido responsable de la estabilización de los conflictos políticos que oponían el Ejecutivo al Parlamento. De esta manera, se defiende la hipótesis de que los conflictos existentes anteriormente permanecieron y que los cambios reglamentarios propuestos han tenido poco impacto sobre su estabilización.

Palabras clave: política de los estados; Campos Sales; verificación de poderes; elecciones; estabilidad política 